\title{
Survey and prevalence of species causing Alternaria leaf spots on brassica species in Pernambuco
}

\author{
Sami J Michereff ${ }^{1}$; Marissônia A Noronhaㄹ ${ }^{2}$ Maria S Xavier Filha ${ }^{1}$; Marcos PS Câmara ${ }^{1}$; Ailton Reis ${ }^{3}$ \\ ${ }^{1}$ UFRPE, Depto. Agronomia, Av. Dom Manoel de Medeiros s/n, 52171-900 Recife-PE; sami@depa.ufrpe.br; \\ ${ }^{2}$ Embrapa Tabuleiros Costeiros, BR 104 km 85, Campus Delza Gitai, 57100-000 Rio Largo-AL; marissonia@cpatc.embrapa.br; \\ ${ }^{3}$ Embrapa Hortaliças, Lab. Fitopatologia, C. Postal 218, 70359-970 Brasília-DF; ailton@cnph.embrapa.br
}

\begin{abstract}
Brassicaceae family comprises plant species that are very important as vegetable crops, such as the species complex Brassica oleracea and Brassica rapa. Alternaria brassicicola and A. brassicae are among the most important pathogens of Brassicaceae causing Alternaria leaf spot disease. The occurrence and prevalence of Alternaria species causing leaf spots in brassica crops in Pernambuco was acessed, as well as the existence of a possible preference by vegetable host for these pathogens. Twenty-eight fields were surveyed in the Agreste region of Pernambuco state, in the 2005 and 2006 growing seasons. In each year, 10 Chinese cabbage, six cabbage, six cauliflower and six broccoli fields were visited. In each field, 50 leaves showing at least five lesions were randomly collected. Species identification was performed taking into account morphology of the conidia that was compared with literature data. Among the two Alternaria species found, A. brassicae was found in all Chinese cabbage fields while $A$. brassicicola was found in all fields of cabbage, cauliflower and broccoli. Overall, A. brassicicola was more prevalent than $A$. brassicae. In Chinese cabbage there was predominance of $A$. brassicae, with mean prevalence of $91.0 \%$ and $96.5 \%$ in 2005 and 2006. On the other hand, in broccoli and cabbage there was high predominance of $A$. brassicicola, with mean prevalence between $95.1 \%$ and $99.8 \%$. In cauliflower, although the prevalence has been of $A$. brassicicola, high frequency of $A$. brassicae was noted. The frequency of co-occurrence of both Alternaria species was very low. The results of this study reinforce the hypothesis of existence of host preference within species of Alternaria that cause leaf spots in brassica crops, especially when Chinese cabbage, broccoli and cabbage are considered. This information is critical to developing strategies for managing Alternaria leaf spots in Brassicaceae species.
\end{abstract}

Keywords: Brassica oleracea, Brassica rapa, Alternaria brassicae, A. brassicicola, etiology, epidemiology.

\section{RESUMO}

Levantamento e prevalência de espécies causadoras da alternariose em brássicas em Pernambuco

A família Brassicaceae possui espécies importantes como hortaliças, destacando-se as espécies complexas Brassica oleracea e Brassica rapa. Alternaria brassicicola e A. brassicae estão entre os patógenos mais importantes das brássicas causadores da alternariose. Este trabalho teve como objetivos avaliar a ocorrência e a prevalência das espécies de Alternaria causando doenças em brássicas no Estado de Pernambuco, bem como verificar a existência de uma possível preferência por espécie de hortaliça hospedeira. Foram amostradas 28 lavouras de brássicas na região Agreste de Pernambuco, nos anos de 2005 e 2006. Em cada ano foram visitadas 10 lavouras de couve-chinesa, seis de repolho, seis de couve-flor e seis de brócolos. Em cada lavoura foram coletadas aleatoriamente 50 folhas com sintomas de alternariose contendo pelo menos cinco lesões. A identificação das espécies de Alternaria foi realizada com base nas características dos conídios em comparação com as descrições na literatura. Dentre as duas espécies de Alternaria encontradas, A. brassicae foi detectada em todas as lavouras de couve-chinesa, enquanto $A$. brassicicola ocorreu em todas as lavouras de repolho, couve-flor e brócolos. No geral, A. brassicicola foi a mais prevalente nos dois anos de amostragem. Em couve-chinesa houve predominância de A. brassicae, com prevalências médias nas lavouras de 91,0\% e 96,5\% em 2005 e 2006. Por outro lado, em brócolos e repolho houve predominância de $A$. brassicicola, com prevalências médias entre 95,1 e $99,8 \%$, respectivamente. Em couve-flor, embora a predominância tenha sido de $A$. brassicicola, também foi constatada alta frequência de $A$. brassicae. A frequência de lesões com co-ocorrência das espécies de Alternaria foi muito baixa. Os resultados deste trabalho reforçam a hipótese que dentre as espécies de Alternaria causadoras de manchas foliares em brássicas ocorre preferência por hospedeiro, principalmente quando considerados couve-chinesa, brócolis e repolho, o que deve ser levado em consideração no desenvolvimento de estratégias de manejo da alternariose em brássicas.

Palavras-chave: Brassica oleracea, Brassica rapa, Alternaria brassicae, A. brassicicola, mancha-de-alternária, etiologia, epidemiologia.

\section{(Recebido para publicação em 20 de dezembro de 2010; aceito em 12 de março de 2012) (Received on December 20, 2010; accepted on March 12, 2012)}

$\mathrm{B}$ rassicaceae family comprises lots of plant species which are vegetables of great economic importance (D'antuono et al., 2007). Among them, the most cultivated ones in Brazil are classified in the European species (Brassica oleracea), which includes intensively cultivated subspecies, like cabbage (B. oleracea L. var. capitata), green collards, (B. oleracea L. var. acephala), cauliflower (B. oleracea L. var. botrytis) and broccoli (B. oleracea L. var. italica).
Another widely cultivated species in the world and in Brazil is Brassica rapa (Brassica campestris), which complex comprises the eastern group among cultivated Brassicaceae. This complex species is also subdivided in subspecies, 
considering the Chinese-cabagge ( $B$. rapa L. var. pekinensis) the most cultivated one. Other widely cultivated species are the radish (Raphanus sativus), rape (Raphanus sativus L. var. oleifera) and mustard (Brassica juncea) (Dixon, 2007).

Some vegetable species of Brassicaceae family have a great commercial importance in Pernambuco and other Brazilian states. However, Brassicae might have its production limited due to the occurrence of Alternaria leaf spot disease, caused by A. brassicae, A. brassicicola and $A$. japonica (Strandberg, 1992; Mehta et al., 2005; Tewari \& Buchwaldt, 2007; Reis \& Boiteux, 2010). A. brassicae as well as $A$. brassicicola are worldwide occurrence and the main species which infects cultivated plants and some weeds of Brassicaceae family in Brazil (Maringoni, 2005; Reis \& Boiteux, 2010). On the other hand, A. japonica has limited geographic distribution and infects mainly radish (Tewari \& Buchwaldt, 2007). Alternaria leaf spot disease is considered the most common and destructive fungal disease in brassicae, causing considerable damage, from the nursery phase until the reproductive phase (Maringoni, 2005; Mehta et al., 2005). In post-harvest, the disease continues to develop producing big leaf spots which cause yellowing of the leaves, making them not appropriate for consumption (Carrijo \& Rêgo, 2000).

The disease can show up in nursery phase, causing the damping-off in seedlings and necrosis of cotyledons and hypocotyls. In adult plants, initially, the symptoms occur in outer leaves, developing for the whole plant, subsequently. The lesions are small and necrotic. In its development, the lesions become circular, concentric and with a chlorotic halo, usually recovered by conidia, asexual phase structures of the fungus (Maringoni, 2005).

The spots caused by $A$. brassicicola in the leaves are usually smaller than those spots caused by $A$. brassicae, and they present darker color, almost black. Typical symptoms of $A$. brassicicola occur in floral parts, mainly in cauliflower. In Chinese cabbage coalescence of lesions can occur, providing to outer leaves a burned look, which leads to a great depreciation of the product. Seeds in phase of formation, when colonized by fungi, can be destroyed or become empty. Mature seeds, when colonized, carry the mycelium of the pathogen externally and/or internally (Maringoni, 2005).

Alternaria epidemic occur under high relative humidity condition $(>87 \%)$ and high temperatures (A. brassicicola) or moderate (A. brassicae). For the infection, at least, $9 \mathrm{~h}$ of free water in the surface of the plant is necessary (Mehta et al., 2005). The symptoms appear between two and 14 days after the infection, depending on the susceptibility of the cultivar and the environmental conditions. The spread of inoculums occurs through the infected seeds and seedlings and through the wind. The main source of Alternaria inoculum are contaminated seeds, rests of infected crops, weeds and spontaneous host (Maringoni, 2005; Mehta et al., 2005).

Despite the importance of the disease, there are few studies about the occurrence and distribution of the species of Alternaria in Brazil and their possible preference for particular host. Therefore, this work aimed to study, identify and quantify the prevalence of Alternaria species which cause disease in brassicae crops in Pernambuco, as well as a possible preference for host.

\section{MATERIAL AND METHODS}

Study area and sampling - In 2005 and 2006, twenty-eight brassicae fields were visited, randomly chosen, and located in four municipalities in the Agreste Region of Pernambuco state: Camocim de São Félix, Bezerros, Gravatá and Chã Grande. The visits were taken place from September to December period, at temperature of $28.2 \pm 4.6^{\circ} \mathrm{C}$ and relative humidity of $76.5 \pm 7.3 \%$. In each year, 10 Chinese cabbage fields were sampled (cvs. Komachi and Taibyo) and six of each of the species of the following subspecies of B. oleracea: broccoli (cv. Piracicaba Precoce), cauliflower (cv. Verona) and cabbage (cvs. Fuyutoyo and
Matsukaze). The plants aged between 45 and 60 days after transplanting. In each field, fifty leaves showing symptoms of Alternaria leaf spot disease were collected randomly, with at least five lesions in the leaf blade. From each of the five lesions per leaf, fragments of tissues containing fungi structures were taken out and microscope preparations on glass slides containing a drop of blue Aman were made. The slides were, afterwards, observed in optical microscope at 400x magnification.

Identification of Alternaria species - The identification of Alternaria was carried out taking in account the characteristics of the conidia, like size and chain or isolated formation. In cases of doubt, microcultures were prepared in order to confirm the species, through cultivation technique on the blade (Sutton, 1980), using block (1 $\mathrm{cm}^{2}$ ) potato-dextrose-agar medium culture (PDA) put in the center of a sterilized glass blade, deposition of small pieces of mycelium on each side of the block $\left(1 \mathrm{~cm}^{2}\right)$, block cover with sterilized coverslips and incubated at $25 \pm 1^{\circ} \mathrm{C}$. After 72 hours, the coverslip was removed and put on a glass blade containing a drop of blue Aman. The glass blades were observed as described previously. The characteristics of the observed isolates were compared to the characteristics of the Alternaria species described in literature (Ellis, 1971; Simmons, 2007).

Data analysis and summarization The frequencies observed in each of the Alternaria species and their combination within years were compared using Kruskal-Wallis test $(p=0.05)$. The frequency in each species and the combination of them during these years were compared using Mann-Whitney test $(\mathrm{p}=0.05)$.

\section{RESULTS AND DISCUSSION}

The presence of $A$. brassicicola and $A$. brassicae was confirmed in all sampled brassicae in Pernambuco, whereas the presence of $A$. japonica was not recorded. These results confirm the recent observations of Reis \& Boiteux (2010) about the predominance of the two species in cultivation of brassicae 


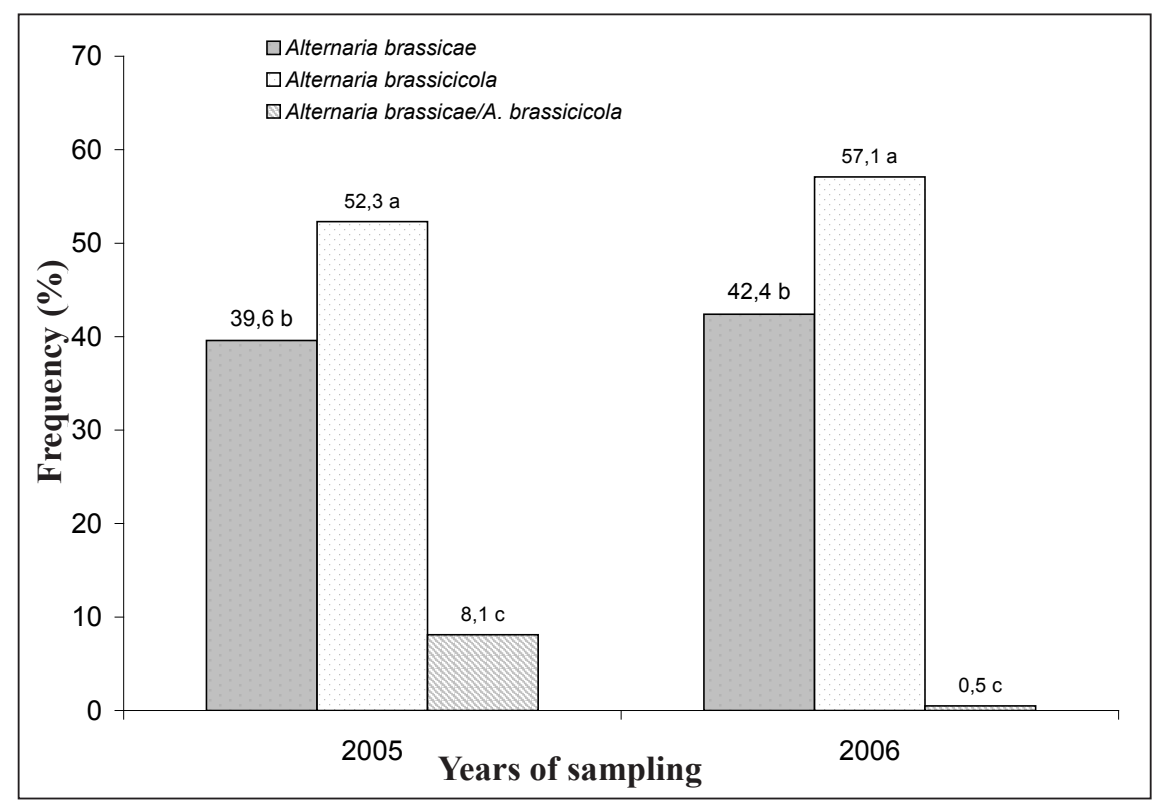

Figure 1. Frequency of Alternaria species on brassica crops in the Agreste Region of Pernambuco State, Brazil, in the years of 2005 and 2006. Means followed by the same letter in each sampling year do not differ by the Kruskall-Wallis test $(p=0.05)$ ) [Freqüência média de espécies de Alternaria em cultivos de brássicas na região Agreste do Estado de Pernambuco, nos anos de 2005 e 2006. Médias seguidas pela mesma letra, dentro de cada ano de amostragem, não diferem significativamente entre si pelo teste de Kruskall-Wallis $(\mathrm{p}=0,05))]$. Recife, UFRPE, 2005/2006.

in Brazil. Alternaria brassicae was observed in all fields of Chinese cabbage sampled, in $66.7 \%$ of the fields of Chinese cabbage and in $16.7 \%$ of cabbage and broccoli fields. On the other hand, A. brassicicola was found in all sampled cabbage, cauliflower and broccoli fields, and in 50\% of Chinese cabbage fields. Therefore, it is possible to say that, apparently, A. brassicae species prefer the Chinese cabbage host (B. rapa) and $A$. brassicicola species prefers $B$. oleracea complex hosts. Similar results were obtained, previously, with these pathosystems in Pernambuco (Peruch et al., 2006) for $A$. brassicae, which was $39.2 \%$ and $42.4 \%$ for 2005 and 2006 , respectively. The presence of the two species in the same lesion was little observed in the year of 2005 (8.5\% of lesions) and hardly ever in the year of 2006 (only $0.5 \%$ ) (Figure 1). This difference in frequency in which the two species were found in the evaluated samples may happen because of the higher number of fields of the species $B$. oleracea (18) in relation to the number of fields of the species B. rapa (10) sampled in each year. However, the preference of A. brassicae for Chinese cabbage and A. brassicicola for brassicae of the European group seems to be clear in the studied region. Furthermore, as the study represents only two years, this tendency may change in the following years, depending mainly on the climate changes and the introduction of new cultivars of brassicae in the region.

When considered the isolated species of brassicae, Chinese cabbage showed higher number of $A$. brassicae, with average prevalence of $91.0 \%$ and $96.5 \%$ for 2005 and 2006, being significantly superior when compared to $A$. brassicicola or the combination of both (Table 1). On the other hand, A. brassicicola predominated in other brassicae, with prevalence of $99.8 \%$ and $99.3 \%$ in broccoli, and $95.1 \%$ and $99.5 \%$ in cabbage and $61.6 \%$ and $64.2 \%$ in cauliflower, in 2005 and 2006, respectively. The frequency of $A$. brassicae in cauliflower reached $29.7 \%$ and $32.8 \%$ in 2005 and 2006, but it was significantly lower than the observed results for $A$. brassicicola (Table 1).

According to the results observed in this study, we can say that different

Table 1. Frequency (\%) of Alternaria species on different host species in the Agreste region of Pernambuco State (freqüência(5) de espécies de Alternaria em diferentes espécies hospedeiras na região Agreste do Estado de Pernambuco). Recife, UFRPE, $2005 / 2006$.

\begin{tabular}{|c|c|c|c|c|c|c|c|c|}
\hline \multirow{2}{*}{ Species and combinations } & \multicolumn{2}{|c|}{ Broccoli (6)* } & \multicolumn{2}{|c|}{ Chinese cabbage (10) } & \multicolumn{2}{|c|}{ Cauliflower (6) } & \multicolumn{2}{|c|}{ Cabbage (6) } \\
\hline & 2005 & 2006 & 2005 & 2006 & 2005 & 2006 & 2005 & 2006 \\
\hline A. $b r c$ & $0,1 \mathrm{bA}^{* *}$ & $0,4 \mathrm{bA}$ & $91,0 \mathrm{aA}$ & $96,5 \mathrm{aA}$ & $29,7 \mathrm{bA}$ & $32,8 \mathrm{bA}$ & $2,3 \mathrm{bA}$ & $0,2 \mathrm{bA}$ \\
\hline A. brassicicola & $99,8 \mathrm{aA}$ & $99,3 \mathrm{aA}$ & $1,9 \mathrm{bA}$ & $2,7 \mathrm{bA}$ & $61,6 \mathrm{aA}$ & $64,2 \mathrm{aA}$ & $95,1 \mathrm{aA}$ & $99,5 \mathrm{aA}$ \\
\hline A. brassicae/A. brassicicola & $0,1 \mathrm{bA}$ & $0,3 \mathrm{bA}$ & $7,1 \mathrm{bA}$ & $0,8 \mathrm{bB}$ & $8,7 \mathrm{cA}$ & $3,0 \mathrm{cA}$ & $2,6 \mathrm{bA}$ & $0,3 \mathrm{bA}$ \\
\hline
\end{tabular}

*values in parentheses indicate the number of visited fields of each brassica specie. **Means followed by the same small letter in the columns and capital letter in the rows, in each host, do not differ by the Kruskall-Wallis and Mann-Whitney tests $(\mathrm{p}=0.05)(*$ valores entre parênteses indicam o número de lavouras visitadas de cada espécie de brássica; **Médias seguidas pela mesma letra minúscula na coluna e maiúscula na linha, dentro de cada hospedeira, não diferem significativamente entre si pelos testes de Kruskall-Wallis e Mann-Whitney $(\mathrm{p}=0,05)$, respectivamente). 
crops of brassicae can work as efficient source of inoculum of $A$. brassicae and $A$. brassicicola for new plantings. Studies of cross inoculation, in which all the isolates are inoculated in all the species of host, are necessary to confirm if the inoculum coming from the fields or cultural remains of species would also be suitable according to the pathogenicity and virulence in a distinct species. In another study, Reis $\&$ Boiteux (2010) observed that isolates of $A$. brassicae and $A$. brassicicola were able to infect and cause some level of symptoms in brassicae of european and oriental groups, as well as some brassicae weeds. However, different levels of quantitative resistance in some hosts were also observed and characterized, mainly for the presence of lesions in smaller sizes.

As observed in other studies (Verma \& Saharan, 1994; Peruch et al., 2006; Reis \& Boiteux, 2010), the results in this work reinforce the evidence that among the species of Alternaria which cause diseases in brassicae in Pernambuco, preference for host occurs, mainly in Chinese cabbage, broccoli and cabbage.
This aspect should be considered in the development of strategy for management of Alternaria, mainly involving the use of resistant cultivars and crop rotation with different species of brassicae, considering the species of the pathogen prevailing in each species of brassicae.

\section{REFERENCES}

CARRIJO IV; RÊGO AM. 2000. Doenças das brássicas. In: ZAMBOLIM L; VALE FXR; COSTA H (eds). Controle de doenças de plantas: hortaliças. Viçosa: Universidade Federal de Viçosa. v.2, p. 335-371.

D'ANTUONO LF; ELEMENTI S; NERI R. 2007. Sensory attributes, health promoting aspects and new uses of edible Brassicaceae. Acta Horticuturae 741: 65-72.

DIXON GR. 2007. Vegetable brassicas and related crucifers. Wallingford: CABI. 327p.

ELLIS MB. 1971. Dematiaceous hyphomycetes. Kew: Commonwealth Mycological Institute. 608p.

MARINGONI AC. 2005. Doenças das crucíferas (brócolis, couve, couve-chinesa, couve-flor, rabanete, repolho e rúcula). In: KIMATI H; AMORIM L; BERGAMIN FILHO A; CAMARGO LEA; REZENDE JAM (eds). Manual de fitopatologia: doenças das plantas cultivadas. 3. ed. São Paulo: Agronômica
Ceres, p. 285-291.

MEHTA N; SANGWAN MS; SAHARAM GS. 2005. Fungal diseases of rapeseed mustard. In: SANGWAN MS; SAHARAM GS, MEHTAN. Diseases of oilseed crops. New Delhi: Indus Publishing Company. p. 15-86.

PERUCH LAM; MICHEREFF SJ; ARAÚJO IB. 2006. Levantamento da intensidade da alternariose e podridão negra em cultivos orgânicos de brássicas em Pernambuco e Santa Catarina. Horticultura Brasileira 24: 464-469.

REIS A; BOITEUX LS. 2010. Alternaria species infecting brassicaceae in the Brazilian neotropics: geographical distribution, host range and specificity. Journal of Plant Pathology 92: 661-668.

SIMMONS EG. 2007. Alternaria: an identification manual. Utrecht: CBS Fungal Biodiversity Centre. $775 \mathrm{p}$.

STRANDBERG JO. 1992. Alternaria species that attack vegetable crops: biology and options for disease management. In: CHELKOWSKI J; VISCONTI A (eds). Alternaria: biology, plant disease and metabolites. London: Elsevier, p. 175-208.

SUTTON BC. 1980. The coelomycetes. Kew: Commonwealth Mycological Institute. 696p.

TEWARI JP; BUCHWALDT L. Diseases caused by fungi and oomycetes. In: RIMMER SR; SHATTUCK VI; BCHWALDT L (eds). Compendium of Brassica diseases. St. Paul: APS Press, p. 15-18.

VERMA PR; SAHARAM GS. 1994. Monograph on Alternaria diseases of crucifers. Saskatoon: Minister of Supply and Services Canada. 162p. 